\title{
PAROKI: MENGHADAPI PERSIMPANGAN BARU
}

\author{
Oleh: Fabianus Selatang ${ }^{1}$
}

\begin{abstract}
Abstrak:
Tujuan tulisan ini ialah untuk melihat konsep Paroki, kaum awam, pelayanan dalam paroki, persoalan-persoalan serta tantangan-tantangan yang dihadapi oleh Paroki sebelum Konsili Vatika II sampai sekarang. Kemudian, bagaimana kita menghidupi Paroki dan saran-saran pastoral kontekstual yang diperlukan zaman sekarang. Metode yang dipakai oleh penulis adalah studi literer atau kepustakaan dengan menggunakan pendekatan kualitatif. Dari sumber yang ada, penulis mendeskripkan secara tekstual mengenai paroki dalam menghadapi persimpangan baru. Setelah penulis menggali, meneliti dan merumuskan dari berbagai sumber, maka ada beberapa temuan penting. Pertama, Gereja adalah umat Allah. Konsep ini membawa pengaruh positif yang besar terhadap umat Katolik terutama dalam kaitan dengan panggilan untuk menjadi pelayan. Hidup matinya sebuah Paroki bukan semata-mata di tangan pastor Paroki, tetapi ada di tangan semua umat yang dibaptis. Kedua, semua orang dipanggil pada tugas yang sama yakni melanjutkan karya penebusan Kristus dan menguduskan dunia. Panggilan ini berkat rahmat Sakramen Pembaptisan. Ketiga, Gereja dan karya-karyanya mesti terbuka terhadap perubahan dan perkembangan serta tuntutan dunia. Gereja dihadapkan pada persimpangan baru dengan segala tuntutan dunia yang termanifestasir dalam kerinduan umat. Di sinilah diperlukan sebuah pola pendekatan dan pendampingan yang bijaksana agar tidak ada yang diabaikan dan yang lain merasa diperhatikan. Oleh karena itu, saran-saran pastoral tetap terbuka terhadap situasi dan kebutuhan sebuah medan pastoral paroki.
\end{abstract}

Kata kunci: Paroki, Pelayanan Pastoral, Gereja, Kaum awam.

\section{Pengantar}

$\mathrm{J}$ udul di atas sangat menggugah, sekaligus menyimpan sejuta pertanyaan. Untuk menyelami muatan yang terkandung dalam judul di atas, penulis mengawalinya dengan kisah seorang pribadi yang bernama Eddie. Ia tidak memiliki keluarga dan seorang pensiunan. Beberapa anggota paroki membawanya untuk menghadiri perayaan ekaristi. Ia selalu menyalami umat dengan menyapa "selamat Pagi". Singkat cerita Eddie meninggal. Yang ada dalam hati umat adalah kenangan akan sosok pribadinya, hidupnya dan sebagainya. Eddie meninggal sebagaimana ia hidup. Ia seorang pribadi yang gembira. Ia meninggalkan harta yang tiada taranya yakni keceriaan, kebahagiaan di dalam hati umat paroki yang adalah keluarganya.

Cerita di atas mengantar kita untuk menyelami arti dan peranan paroki. Paroki memainkan peranan penting dalam kehidupan umat Katolik. Hidup dalam paroki merupakan pengalaman pengenalan pertama umat akan Gereja. Paroki merupakan bagian utama dari 
kehidupan umat Katolik. Dewasa ini, setiap Paroki pasti akan "menghadapi persimpangan baru" dalam mewartakan Sabda Yesus. Persimpangan baru yang dimaksud antara; kebutuhan spiritual umat, situasi keluarga katolik, pendatang baru dalam paroki, masalah ekonomi, pendidikan, budaya baru, gaya hidup baru dan sebagainya. Dalam tulisan ini, penulis akan memaparkan enam bagian. Pertama, pengantar. Kedua, pergeseran perspektif teologis dan pastoral. Ketiga, menghadapi persimpangan baru. Keempat, dinamika kehidupan internal paroki. Kelima, tantangan dan peluang pastoral bagi Gereja Indonesia. Keenam, saran-saran pastoral yang kontekstual.

\section{Pergeseran Perspektif Teologis dan Pastoral}

\section{a. Konsili Vatikan II}

Konsili Vatikan II meninjau kembali dasar teologis yang melandasi kehidupan paroki. Gereja sebagai umat Allah, itulah gagasan atau pengertian yang terkandung dalam Konstitusi Dogmatik mengenai Gereja khususnya Lumen Gentium. Konsep Gereja sebagai umat Allah membawa perubahan yang sangat besar di dalam pelayanan Paroki, struktur organisasi dan membawa transformasi tanggung jawab umat paroki. Konsep pelayan yang sebelumnya hanya terbatas pada kaum tertahbis atau pastor sentris, tetapi sekarang semua orang dipanggil untuk menjadi pelayan berkat rahmat pembaptisan yang diterima oleh setiap umat katolik.

b. Setelah Konsili Vatikan II

Setelah Konsili Vatikan II, ada perubahan pandangan mengenai pendidikan agama, liturgi, pakaian liturgi, aturan puasa dan pantang. Tekanannya pada peran kaum awam dalam paroki. Sebagai bentuk tindakan kesaksian, umat Allah diajak untuk peka terhadap kebutuhan dan persoalan yang terjadi di dalam masyarakat. Kaum awam mengambil bagian terutama dalam pelayanan liturgi, katekese dan kegiatan sosial. Dalam Lumen Gentium (Art.33), dikatakan bahwa kaum awam dipanggil untuk menghadirkan dan mengaktifkan Gereja di daerah-daerah dan keadaan-keadaan, tempat Gereja tidak menggarami dunia. Perubahan ini membawa dua dampak. Pertama, yang antusias menerima perubahan ini. Bagi mereka ini adalah kesempatan untuk meningkatkan iman dan kesetiaan mengikuti Yesus Kristus. Kedua, yang tidak menerima. Perubahan ini justru menimbulkan kebingungan. Letak kebingungannya ialah di satu sisi, pendidikan dan pembinaan iman hanya terjadi dalam Seminari dan Universitas Katolik. Di sisi lain, pendidikan dan pembinaan iman diperluas sampai ke paroki-paroki. Inilah yang terjadi pada akhir tahun 1960-an.

c. Tahun 1970-1980-an

Perubahan yang terjadi di atas, kini sudah nampak dengan munculnya pelayanan dan pembinaan di paroki-paroki. Bidang pembinaan itu antara lain pendidikan agama, tata cara liturgi, kesadaran dan keterlibatan dalam kegiatan sosial, memelajari soal perceraian dalam 
perkawinan, pastoral keluarga, ritus inisiasi Kristen orang dewasa dan pelayanan kaum muda. Kaum awam dilibatkan dalam lektor, misdinar, pro-diakon, koor dan sebagainya.

d. Tahun 1990-an

Disposisi para pelayan penuh irama. Kaum awam Katolik melayani dalam berbagai cara seperti liturgi dan katekese. Umat paroki berjalan menyeberangi sebuah jalan baru. Katekese menjadi tantangan tersendiri dalam membina kaum awam karena harus dibekali dengan pendidikan agama yang baik dan memadai. Inilah bentuk simbolis kehadiran Gereja yang dinamis. Kehadiran Gereja yang dinamis inilah yang membawa perubahan dan meningkatkan stabilitas dalam komunitas Katolik.

e. Sekarang

Dewasa ini pelayan paroki secara terus menerus ditingkatkan dalam hal kualitas dan kompetensinya. Arah teologi dan pastoral menurut Konsili Vatikan II, kini mendapat tempat. Di persimpangan baru ini, hal-hal penting sedang terjadi di berbagai kalangan umat paroki. Hal-hal penting itu antara lain, kehidupan spiritual, sosial, bidang pendidikan, bidang liturgi dan pelayanpelayan paroki (tim pastoral). Pelayan-pelayan paroki sekurang-kurangnya sudah dibekali dengan pendidikan yang memadai.

\section{Menghadapi Persimpangan Baru ${ }^{2}$}

Ada tiga poin penting yang ingin kita gali dari frasa persimpangan baru. Ketiga poin ini juga menjadi tantangan bagi sebuah paroki.

a. Misi dan Pelayanan Paroki Dalam Dunia Modern

Di tengah dunia modern ini, harapannya agar paroki-paroki sekarang dan yang akan datang tetap berdiri kuat. Kekuatan itu terletak pada keyakinan bahwa paroki memberikan peluang bagi umat untuk bertumbuh dalam hidup rohani, pengetahuan Kitab Suci, Katekese, liturgi, dan juga semangat keberpihakan kepada kaum miskin. Semua hal di atas memiliki hubungan dengan rahmat pembaptisan. Bahwasannya, melalui rahmat pembaptisan, semua orang dipanggil dan diutus untuk melayani dunia. Katekismus Gereja Katolik art. 897 dengan tegas dan jelas mengungkapkan panggilan kaum awam. Kaum awam adalah semua orang beriman kristiani kecuali mereka yang termasuk golongan imam atau status religius yang diakui dalam Gereja. Jadi, kaum awam beriman kristiani, yang berkat baptis telah menjadi anggota tubuh Kristus, terhimpun menjadi umat Allah, dengan cara mereka sendiri ikut mengemban tugas imamat, kenabian, dan rajawi Kristus, dan dengan demikian sesuai dengan kemampuan mereka melaksanakan perutusan segenap umat Kristiani dalam Gereja dan dunia (Bdk. LG art.31).

b. Keterlibatan Kaum Muda dalam Pelayanan Paroki

Keterlibatan kaum awam dalam kepengurusan dan pelayanan paroki menunjukkan nilai kekatolikannya mulai bertumbuh. Dalam buku, Sons and Daugthers of the light: A Pastoral Plan 
for Ministry with Young adults dikatakan bahwa " Banyak orang dewasa bersedia untuk berbagi keterampilan kepemimpinan dalam pelayanan dan spiritualitas yang mereka miliki secara mendalam kepada komunitas-komunitas baru dalam paroki". Dari pernyataan di atas terungkap dengan jelas akan peran serta kaum muda dalam paroki. Paroki-paroki harus terbuka menerima kaum muda dan mendorong mereka untuk saling berbagi. Masa depan sebuah paroki ada di tangan kaum muda. Oleh karenanya, kaum muda harus memiliki semangat berkorban dan jiwa sukarela untuk bekerja bagi paroki.

Paroki-paroki membuat terobosan baru dalam mewartakan Sabda Tuhan. Tuntutantuntutan ini perlu agar terbuka terhadap tantangan dan berpegang teguh pada komitmen terhadap nilai-nilai Kristiani. Tugas paroki adalah menyiapkan umat paroki, secara khusus kaum muda untuk menjadi pelayan. Ajaran sosial Gereja mendorong paroki-paroki untuk mendidik umatnya agar mampu melihat sesama dari berbagai lapisan dan bangsa sebagai saudara dan saudari. Artinya, kaum muda harus membangun relasi dengan semua orang, menghargai semua budaya dan agama sambil tetap memertahankan dan setia kepada iman Katolik. Oleh karena itu, kaum muda perlu dibekali dengan pengetahuan yang mendalam akan iman Katolik, katekese yang efektif dan mendalam, sehingga mereka dapat membagikan imannya kepada sesama.

c. Dialog dengan Kebudayaan Dunia dan Agama-Agama

Langkah dialog yang dilakukan oleh Gereja adalah inkulturasi. Inkulturasi memiliki implikasi praktis bagi paroki yang kebanyakan umat non-Kristiani, yang bekerja di kantor dan pabrik dan sebagainya. Selain soal inkulturasi, dalam menyikapi perkembangan media masa, di satu sisi umat dituntut untuk menyatu dengan dunia, tetapi juga memertahankan identitas mereka sebagai orang Katolik. Umat diharapkan untuk mampu mengaplikasikan nilai-nilai iman Kristiani di tengah dunia. Selain mengaplikasikan nilai-nilai iman, umat juga harus bisa menolak hal-hal yang bertentangan dengan iman Kristiani.

Peran paroki adalah memberikan keyakinan kepada umatnya bahwa Roh Kudus berkarya dalam hati umatnya sehingga mereka mampu melihat spiritualitas dan cara-cara yang terbaik dalam melayani lingkungan-lingkungan, keluarga-keluarga dan seterusnya. Oleh karena itu, mesti belajar pada Yesus Sang Guru dan Teladan kita. Peran paroki seperti halnya dokter yang dapat memberikan kesembuhan secara rohani kepada umatnya. Sebagaimana Yesus juga mau melayani dan menyebuhkan yang sakit. Demikian pula dengan peran paroki. Josephine Dolan menyatakan bahwa "the teaching and example of Jesus Christ had a profound influence on the emergence of gifted nursing leadership as well as on the expansion of the role of the nurse. Christ's own healing activities and attitude toward the sick provided the best model of caring for the nurse, Dolan point out, for instead of saying the word and healing the sick, Christ gave individual attention tp the needs of all by touching, anointing and taking by the hand. ${ }^{3}$

\section{Menghadapi Dinamika Kehidupan Internal Paroki}


Persoalan dan perbedaan etnis, keluarga, sosial dan lingkungan merupakan persoalan internal paroki yang dihadapi oleh Gereja sekarang dan yang akan datang. Kegembiraan dan harapan, duka dan kecemasan umat Katolik zaman sekarang, tentulah merupakan kegembiraan dan harapan, duka dan kecemasan seluruh umat Allah. ${ }^{4}$ Dalam menghadapi semunya itu, Gereja tentu saja membutuhkan landasan iman yang kuat. Landasan iman Gereja adalah Yesus sendiri. Yesus telah menunjukkan teladan dalam hal pelayanan dan pengorbanan. Yesus Kristuslah yang menjadi alasan kehidupan dan pelayanan paroki. Hidup manusia bersatu dengan Yesus dalam cinta akan Allah, sebagaimana terungkap dalam kata-kata Our Hearts Were Burning Within Us: "Iman seorang Kristiani adalah hidup dalam kemuridan untuk Yesus Kristus". Gereja merayakan iman akan Yesus dalam perayaan ekaristi. Ekaristi dan Gereja tidak dapat dipisahkan. Oleh karena itu, hidup dan karya Gereja tidak dapat dipisahkan dari ekaristi, sebab ekaristi adalah sumber hidup Gereja.

Setelah Konsili Vatikan II, dinamika paroki bergeser. Dalam Konsitusi Pastoral Tentang Gereja dalam Dunia Modern (GS) dikatakan bahwa tantangan-tantangan agama Katolik terhadap pengaruh dunia melalui kehadiran mereka. Kehidupan agama Katolik dalam sebuah masyarakat pluralistik diundang untuk mencari ke luar terhadap kebudayaan yang lebih luas melalui ekumenis dan keterlibatan sosial. Nilai-nilai kebudayaan memengaruhi paroki-paroki.

Pada saat yang sama, Gereja juga berhadapan dengan relativisme budaya, materialisme dan individualisme yang dapat dengan mudah mengganggu umat paroki dari berbagai masalah inti kehidupan. Gereja Katolik tidak hanya berdiam diri atau mengelak dari situasi ini atau hanya melindungi dirinya sendiri dari bentuk godaan dari masyarakat sekular. Tantangan-tantangan ini akan menggerogoti keluarga, pekerjaan dan kehidupan paroki.

\section{a) Perbedaan Etnis}

Kesadaran akan pentingnya peran umat paroki dalam menyambut umat baru menjadi perhatian utama sebuah paroki. Perubahan susunan etnis merupakan sebuah tantangan paroki. Beberapa perubahan etnis memberikan banyak kesempatan bagi paroki untuk memerkaya pelayanan liturgi, katekese dan pastoral yang diperoleh dari kekayaan warisan kebudayaan yang dibawa oleh kelompok etnis-etnis tertentu.

Bentuk tanggapan paroki menanggapi perbedaan etnis akan sangat memberikan dampak terhadap pelayanan dan keberadaan umat. Pertanyaan ialah kekayaan kebudayaan dari masingmasing etnis memberikan manfaat bagi paroki? Apakah orang dari berbagai latar belakang etnis membuat umat paroki menjadi aktif? Seringkali paroki-paroki menanggapi secara berangsurangsur, tetapi tidak ada sukses tanpa sebuah komitmen dari umat paroki terhadap kesediaan menerima umat yang baru. Komitmen itu antara lain;beberapa lagu dari etnis, kastekese, festival, makanan-makanan dan adat istiadat dapat dimanfaatkan dalam paroki. Festival makanan yang diseponsori dari beberapa etnis mungkin menjadi langkah pertama terhadap event-event yang lain yang menekankan perbedaan dimensi-dimensi kebudayaan seperti perayaan hari Natal, musik dan pakaian. 
Dalam seruan para Uskup Amerika tentang kesatuan dan perbedaan: menyambut orang baru di antara kita, mengangkat isu imigran dalam negara mereka. Para uskup menyambut dan menanggapi dengan sangat ramah budaya-budaya mereka. Dalam hubungan dengan paroki, para uskup mengatakan bahwa "Kaum imigran akan mengalami penerimaan Gereja secara pribadi pada tingkat paroki. Karena itu, para pastor dan staf pastoral, hendaknya diisi dengan sebuah semangat baru, menanggapi dan berharap memahami sedikit demi sedikit budaya baru".

b) Berbagai Bentuk atau Susunan Keluarga

Fakta bahwa banyak anak tidak tinggal bersama orang tuanya. Perbedaan keluarga terus meningkat. Pelayan-pelayan pastoral hendaknya membuka mata terhadap kemungkinankemungkinan yang mana seorang anak juga membutuhkan pendidikan agama, komuni pertama dan sakramen krisma yang berasal dari ayah dan ibu mereka. Tak jarang kita jumpai juga bahwa banyak anak yang tidak tinggal dengan orang tuanya, tetapi dengan nenek/kakek mereka. Selain itu, tidak sedikit juga anak-anak yang lahir dari keluarga yang orang tuanya berbeda iman dan anak-anak harus tinggal dalam keluarga yang orang tuanya nikah beda agama atau keluarga campuran. Mungkin juga banyak keluarga yang tidak memerhatikan pendidikan agama Katolik bagi anak-anak mereka. Paus Yohanes Paulus II, dalam Apostolic Exhortation, Familiaris Consortio art. 37 menyatakan bahwa:

"Bahkan di tengah kesulitan-kesulitan karya pendidikan, kesulitan-kesulitan yang kadang lebih besar dewasa ini, para orang tua harus dengan yakin dan berani mendidik anak-anak mereka tentang nilai- nilai esensial di dalam hidup manusia. Anak- anak harus tumbuh dengan sikap yang benar tentang kemerdekaan [ketidakterikatan] terhadap barang- barang materi, dengan menerapkan gaya hidup yang sederhana dan bersahaja, yakin bahwa "manusia itu lebih berharga karena apa adanya dia daripada karena apa yang dia miliki."

Di sisi lain, kita juga menjumpai banyak juga orang tua apapun latar belakang keluargany mencoba menyediakan bagi anak-anak mereka dengan sebuah rumah yang bagus, pendidikan religious dan sebagainya. Singkat kata, apapun bentuk susunan keluarga, inilah lahan pelayanan pastoral Gereja. Saat yang sama, ini juga menjadi tantangan Gereja dalam memberikan pelayanan kepada umatnya.

Anugerah Tuhan yang istimewa dijumpai di setiap keluarga tanpa memerhatikan latar belakangnya. Pelayan pastoral dapat membantu para orang tua untuk memberikan pengetahuan iman Katolik serta menyadarkan mereka tentang tanggung jawab kepada anak-anak dalam semangat Yesus Kristus. Dalam Katekismus Geraja Katolik dikatakan bahwa "Komunitas Kristiani mesti memberikan perhatian khusus kepada para orang tua. Dalam artian, kontak pribadi, pertemuan, kursus dan juga katekese. Komunitas Kristiani mesti membantu mereka untuk menerima tanggung-jawab mereka, secara khusus pendidikan iman anak mereka.

"Pendidikan Kristiani itu tidak hanya bertujuan pendewasaan pribadi manusia, melainkan terutama hendak mencapai, supaya mereka yang telah dibaptis langkah demi langkah semakin mendalami misteri keselamatan, dan dari hari ke hari makin menyadari kurnia iman yang telah mereka terima; supaya mereka belajar menyembah Allah Bapa dalam Roh dan kebenaran (lih. Yoh 4:23), terutama dalam perayaan Liturgi; supaya mereka dibina untuk menghayati hidup 
mereka sebagai manusia baru dalam kebenaran dan kekudusan yang sesungguhnya (Ef 4:2224); supaya dengan demikian mereka mencapai kedewasaan penuh, serta tingkat pertumbuhan yang sesuai dengan kepenuhan Kristus (lih. Ef 4:13), dan ikut serta mengusahakan pertumbuhan Tubuh Mistik. Selain itu hendaklah umat beriman menyadari panggilan mereka, dan melatih diri untuk memberi kesaksian tentang harapan yang ada dalam diri mereka (lih. 1Ptr 3:15) serta mendukung perubahan dunia menurut tata-nilai Kristiani ..."

c) Perbedaan Ekonomi Umat

Beberapa orang seringkali duduk berdampingan di dalam Gereja setiap hari Minggu, tanpa sadar akan keadaan orang lain. Perbedaan sosial dan ekonomi antara yang kaya yang miskin semakin berkembang. Paroki ditantang dalam melakukan tugas pelayanan khususnya bagaimana melakukan pelayanan tanpa memperhatikan latar belakang kondisi ekonomi mereka. Gereja sebagai umat Allah memiliki sikap solidaritas terhadap sesama. Salah satu hal yang bisa dilakukan oleh paroki adalah mengerakkan umat yang mampu untuk membantu atau bersolidaritas dengan umat yang mengalami kekurangan. Paroki bisa menjadi penghubung antara umat paroki yang membutuhkan dengan mereka yang menyediakan bantuan. Dalam konteks ini, kaum awam menjadi volunter-volunter dalam mengumpulkan dana, barang-barang kebutuhan pokok dan menyalurkannya kepada umat yang membutuhkannya. Keterlibatan awam ini menjadi kesempatan bagi mereka dalam melayani sesama terutama pelayanan terhadap kaum miskin.

d) Memunculkan Peran Kaum Awam

Paroki perlu keterlibatan aktif kaum awam dalam pelayanannya. Keterlibatan dalam karyan pelayanan, membantu kaum awam bertumbuh dalam imannya. Inilah salah satu cara yang dilakukan dalam gereja protestan. Mereka memiliki komitmen untuk membantu anggota baru mengenali tanggung jawab mereka terhadap komitmen pembaptisan yang telah mereka terima. Orang Katolik juga menanggapi panggilannya untuk memberikan diri bagi karya pelayanan dalam paroki. Mereka memberikan dirinya, seperti waktu, bakat, dan bahkan harta. Uang memang penting untuk sebuah paroki, namun hal ini sama pentingnya dengan waktu dan bakat untuk karya pelayanan itu. Untuk meningkatkan peran kaum awam dalam pelayanan paroki, maka pemimpin paroki perlu merencanakan model pelayanan baru. Sering kali muncul persoalan, misalnya adanya kecemburuan atau persoalan politik, pemimpin paroki harus campur tangan dalam mengatasinya demi pelayan paroki yang efektif.

e) Spiritualitas Kaum Awam

Salah satu karya pelayanan paroki yang sangat penting ialah perhatian terhadap kehidupan rohani atau spiritual umat. Sekarang, sedang berkembang bidang pembinaan atau pelayanan terhadap spiritualitas kaum awam Katolik. Sebelumnya, minat itu hanya ditujukan kepada kaum religius. Pengembangan hidup spiritual dibentuk melalui, misalnya pembelajaranpembelajaran Kitab Suci, hidup para santo/a, kesempatan-kesempatan berdoa, rekoleksi, dan bimbingan retret-retret bagi warga paroki dari berbagai umur, latar belakang etnis dan kondisikondisi sosial ekonomi. Ini merupakan salah satu cara untuk mengarahkan kesadaran kaum awam tentang panggilannya dalam Gereja dan dunia. 
Paroki-paroki diundang untuk memusatkan pelayanan mereka pada formasi iman orang dewasa. Paroki memberikan skil-skil pendampingan spiritual dan menawarkan konseling spiritual. Pendampingan spiritual berarti satu orang awam berjalan bersama orang lain sebagai teman dalam saat baik dan sulit. Dengan pendampingan yang baik, tercukupinya rasa haus akan hubungan yang lebih dalam dengan Allah dan juga menjadi cara untuk membantu mereka bertumbuh dalam hidup rohani dalam hidup sehari-hari.

f) Kepemimpinan Pastoral

Pemimpin pastoral adalah seorang yang dipakai oleh Tuhan untuk memberitakan Injil. Sebagai seorang pastor paroki, pelayanannya harus menyentuh kebutuhan umat dan menanggapai karunia yang telah diberikan Tuhan dan menggunakan karunia-karunia itu untuk menginspirasi hidup orang lain untuk mengikuti Kristus. Menurut Howard John Clinebell, kepemimpinan pastoral yang menggabungkan keterampilan seorang pendidik yang kreatif, seorang fasilitator kelompok yang efektif, dan para aktivis politis, dapat membantu terciptanya suatu gereja yang mempunyai pengaruh yang sangat penting untuk perubahan sosial. ${ }^{5}$

g) Agenda-agenda Berbeda dan Berbagai Tuntutan

Semua keputusan paroki dimaksudkan untuk melayani kebutuhan umat. Terkadang ditantang ketika berhadapan dengan persoalan mengenai prioritas-prioritas paroki. Oleh karena itu, perlu fokus yang lebih tinggi untuk membangun gereja yang baru, melayani kaum miskin, membuka komunitas persaudaraan dalam sebuah paroki, menguatkan bidang liturgi atau mengembangkan formasi religius anak-anak dengan lebih baik dan program-program pelayanan kaum muda. Beberapa persoalan ini menantang sebuah paroki untuk memilah-milah prioritasprioritas dalam terang ajaran Yesus.

h) Bermacam Tingkat Iman dan Perspektif Moral

Dalam survei terhadap kaum muda katolik, seorang pelayan melaporkan hasil-hasil diperoleh. Beberapa responden mengatakan bahwa mereka percaya pada Allah namun tidak membuat komitmen pada Yesus atau Gereja. Yang lain percaya kepada Allah dan Yesus tetapi tidak membuat komitmen kepada Gereja. Jumlahnya kecil yang percaya dan komitmen pada Allah, Yesus dan Gereja. Tanggapan-tanggapan mereka menunjukkan bahwa perjalanan iman mereka berbeda. Dengan menduga bermacam level iman, ritus inisiasi Kristiani bagi orang dewasa mengingatkan paroki untuk menyediakan kesempatan yang berbeda bagi orang untuk menapaki perjalanan imannya yang unik bersama Allah. Dengan ini, mereka mendukung proses perubahan dalam kehidupan setiap orang. Dukungan seperti itu harus dikritisi, berbeda untuk level iman Katolik yang aktif dan tidak aktif.

Hal ini penting bagi pelayan pastoral untuk menempatkan masalah-masalah moral dalam terang ajaran Gereja saat mengajar, berkotbah dan menasihati umat. Tidak seperti generasi sebelumnya, beberapa orang Katolik memberikan sedikit penghargaan mengenai pengajaran yang benar dan salah tentang isu-isu yang mempengaruhi hidup mereka. Banyak orang Katolik 
mengatakan bahwa mereka menerima dasar ajaran-ajaran Katolik, tetapi tidak setuju dengan persoalan seperti kontrol kelahiran, moralitas perang, seks pranikah dan hukuman mati.

i) Kehausan Hidup Komunitas

Generasi sekarang haus akan relasi persaudaraan yang melampaui aktifitas fungsional. Untuk mendapatkan relasi persaudaraan seperti itu, beberapa orang bergabung dalam kelompok salah. Yang lain menggantikan kebutuhan relasi itu dengan uang, kerja, olah raga dan relasi persaudaraan yang dangkal untuk kekurangan dalam diri mereka. Kunci kesuksesan karya pelayanan parokial ditentukan oleh terpenuhinya kehausan rohani dan relasi persaudaraan yang bermakna bagi umat paroki. Anna Marie Eckert menyatakan bahwa "Young people will be able to learn from their peers, find rerfuge in common struggles, and provide direction and insihgt to others who are at a different place on their faith journey. When we are intentional about building community intergenerationally, we give young people the opportunity to learn about discipleship through the live experience of faithful adults, find consolation and support from others outside their families, an provide guides and mentors as they move from childhood into adulthood. Relationships with adults help young people move through this transition with success. ${ }^{6}$

\section{Tantangan dan Peluang Pastoral dalam Konteks Indonesia.}

Dewasa ini, Gereja sebagai sebuah lembaga maupun sebagai pribadi anggota umat Allah tidak jarang selalu berhadapan dengan persimpangan baru ini. Persimpangan baru mau mengatakan soal aneka tantangan yang dihadapi oleh Gereja dan pada saat yang sama Gereja harus mengambil cara atau langkah yang tepat sehingga tidak kehilangan orientasinya. Kita tahu berbagai persoalan yang sedang dihadapi oleh Gereja dewasa ini seperti apa yang terjadi dalam Gereja di Amerika saat ini. Persoalan yang sama juga sebenarnya sedang dihadapi oleh Gereja Katolik di Indonesia. Berhadapan dengan persimpangan baru itu, dibutuhkan berbagai upaya dan refleksi agar Gereja, secara khusus yang ada di Indonesia menemukan langkah yang tepat dalam karya pastoralnya.

1) Kekurangan Imam

Kemajuan dunia saat ini dengan aneka tawarannya yang menggiurkan menjadi salah satu tantangan besar bagi penghayatan kehidupan religius saat ini. Hal ini menjadi nyata ketika beberapa tarekat saat ini sangat sulit untuk mendapatkan calon imam. Dengan memiliki medan pastoral yang luas dan berat, paroki-paroki tersebut hanya dilayani oleh satu atau dua imam. Fakta ini mendorong paroki-paroki untuk memikirkan pendidikan khusus bagi kaum awam untuk terlibat, mengambil bagian dalam karya pastoral paroki sesuai dengan panggilannya dalam Gereja.

2) Partisipasi Kaum Awam 
Kesadaran umat untuk mengambil bagian dalam tugas Gereja masih minim. Banyak umat beranggapan bahwa tugas pelayanan Gereja hanya dilakukan oleh kaum klerus, imam, biarawan/i. Kurangnya kesadaran ini mungkin karena Gereja dalam hal ini pastor paroki tidak memberikan pemahaman yang mendasar mengenai pentingnya keterlibatan kaum awam dalam pelayanan Gereja. Gagasan mengenai pentingnya keterlibatan kaum awam dalam tugas pelayanan Gereja sebagaimana yang tertuang dalam dokumen Konsili Vatikan II belum menyentuh inti diri kaum awam. Tidak mengherankan banyak kaum awam menolak setiap tugas yang dipercayakan oleh pastor paroki.

3) Kesenjangan Ekonomi

Salah satu komitmen pelayanan Gereja saat ini adalah option for the poor. Inilah komitmen sebagai bentuk keperihatinan ketika Gereja, secara khusus yang ada di Indonesia melihat situasi kehidupan sosial ekonomi umat. Taraf kehidupan ekonomi umat Katolik yang ada di Indonesia berbeda-beda, ada yang kaya dan juga yang miskin. Dalam konteks ini, karya pelayanan Gereja hendaknya tidak hanya fokus pada umat-umat yang kaya, tetapi Gereja juga memiliki keperihatinan dengan orang miskin. Demikian juga, Gereja dipanggil menjadi jembatan antara yang miskin dengan yang kaya, terutama dalam memberikan bantuan sejauh bisa dilakukan. Donal Door Pope Francis is fully in line with this position when he maintains that we are called not only to be on the side of the poor but to listen to their insights about God, about Jesus, about the Church, and to allow ourselves to be evangelized by them (EG 198). Another point that has emerged more recently and is strongly confirmed in the teaching of Pope Francis is that the option for the poor and the option for the Earth are not two different realities. ${ }^{7}$

4) Pembentukan Kelompok-kelompok Doa

Kebutuhan manusia tidak hanya dalam hal materil (ekonomi), tetapi juga dalam hal rohani. Kedua kebutuhan ini harus berada dalam keseimbangan. Kebutuhan rohani dipenuhi dengan menghadiri perarayaan Ekaristi, mendengarkan dan merenungkan sabda Tuhan, meditasi, dsb. Dalam konteks ini, tidaklah mengherankan bahwa banyak orang Katolik sekarang tidak hanya rajin menghadiri perayaan Ekaristi, tetapi juga membentuk dan bergabung dalam kelompok-kelompok tertentu untuk menfasilitasi terpenuhinya kebutuhan rohani mereka. Dengan adanya kecenderungan ini, Gereja harus membuka mata dan berusaha mengarahkan dengan lebih baik berbagai kegiatan, sehingga tidak jatuh dalam praktik yang keliru.

\section{5) Perkawinan Campur}

Tantang berat yang dihadapi oleh Gereja dewasa ini ialah kawin campur. Banyak orang Katolik yang melakukan kawin campur. Hal ini tidak bisa dielakan karena umat Katolik hidup di tengah umat yang beragama lain. Persoalannya, kawin campur seringkali berujung pada perceraian. Dampaknya sangat besar, baik kehidupan keluarganya sendiri maupun masa depan anak-anak, pendidikan dan sebagainya. Gereja ditantang untuk bisa menangani persoalan seperti ini. 
6) Inkulturasi

Setiap etnis atau suku memiliki kekayaan budayanya sendiri. Kekayaan budaya itu, di satu sisi dapat menambah khazanah dalam karya pelayanan paroki, tetapi di sisi lain, menjadi tantangan bagi paroki. Tantangannya, bagaimana paroki mengakomodasi kekayaan kebudayaan setiap daerah atau suku sehingga dapat menunjang karya pelayanan pastoral paroki. Jikalau paroki hanya mengangkat dan mengagungkan budaya-budaya dari daerah tertentu, maka suku yang lain menjadi iri hati. Inkulturasi budaya merupakan sebuah upaya untuk mengangkat nilainilai dalam budaya untuk semakin mengembangkan iman umat.

7) Perkembangan Tekhnologi

Perkembangan tekhnologi yang semakin canggih, di satu sisi menjadi sarana yang memudahkan karya pelayanan, tetapi di sisi lain juga menjadi tantangan besar bagi Gereja. Paroki perlu mensiasati agar umat tetap merasa haus dalam menghadiri perayaan ekaristi pada hari minggu. Sebab, manusia dewasa ini lebih memilih hal-hal yang fulgar, fany dan ramai daripada menghadiri perayaan ekaristi pada hari minggu. Contohnya, kaum muda lebih tertarik mengikuti acara di Mall-mall daripada mengikuti pendalaman iman di lingkungan atau kegiatan di Gereja. Oleh karena itu, sarana-sarana "tradisional" tetap diperlukan dalam mewartakan Sada Tuhan. Instruksi pastoral dan sharing iman berlangsung dengan cara ini, dan malah pada tingkat yang lebih maju sarana-sarana komunikasi "tradisional" tetap dapat digunakan untuk menghidupkan suasana melalui permainan dan tarian atau melalui musik dan nyanyian. Semuanya ini sudah ada dan akan terus bertahan lama melampaui semua perkembangan teknologi dan seringkali tetap merupakan cara yang paling efektif dalam komunikasi pastoral. ${ }^{8}$

\section{Saran-saran Pastoral}

Saran-saran pastoral berikut muncul dari pertimbangan berdasarkan paparan di atas:

1) Pelayan kaum muda. Melakukan survei kaum muda dalam paroki untuk memastikan kebutuhan-kebutuhan rohani mereka.

2) Bentuk komite khusus anak muda dan orang dewasa untuk mempelajari mengapa kaum muda kurang berminat dengan tugas pelayanan paroki, kelompok OMK Paroki, Misa dan perayaan sakramen-sakramen. Tujuannya untuk menemukan cara-cara untuk menyambut kembali remaja paroki yang telah meninggalkan gereja.

3) Mengundang kaum muda untuk mengambil bagian dalam sebuah pelayanan di paroki, seperti mengatur pelayanan doa mingguan atau bulanan demi keamanan.

4) Mengembangkan proses untuk pemperbaharui pengaruh positif ruang ibadah paroki daripada mengadakan hal-hal yang bersifat memecah-belah. Bentuklah komite untuk mempelajari persoalan yang ada, survei keberhasilan dan kegagalan dari paroki lain dan membuat rekomendasi khusus. 
5) Mengundang kelompok umat yang sudah tua untuk menanyakan umat paroki baru dari berbagai latar belakang etnis untuk membantu mereka menemukan cara untuk menyambut mereka dan merayakan budaya etnis mereka.

6) Mensurvei umat paroki Katolik yang tidak aktif, untuk memastikan mengapa mereka meninggalkan tidak aktif dan mengundang mereka untuk kembali.

7) Membentuk sebuah komite khusus untuk mempelajari program-program yang tersedia di tempat yang merima kembali orang-orang Katolik yang tidak aktif. Memiliki komite yang memperhatikan program yang berhasil dan akan melayani paroki dengan baik, berpusat pada Kristus.

8) Mengundang para sukarelawan dari komunitas bisnis, baik laki-laki maupun perempuan dalam berbagai profesi, meminta mereka untuk merekomendasikan caracara bagi paroki untuk mendukung warga paroki dalam karya mereka di tempat kerja.

9) Mengundang komite aksi sosial untuk mempertimbangkan cara-cara baru untuk berdiskusi dengan gereja-gereja tetangga bekerja sama yang bertujuan untuk melayani kebutuhan umat.

10) Membentuk suatu kelompok laki-laki jika belum ada, untuk mengarahkan kebutuhankebutuhan spiritual kaum lelaki, mempertimbangkan kemungkinan pelayanapelayanan laki-laki seperti kelompok doa, kelompok sharing, pembaharuan perkawinan, retret-retret dan sebagainya. Hal yang sama dapat dilakukan bagi kaum perempuan.

11) Mempelajari daftar-daftar pelayanan altar paroki untuk memastikan apakah, jika lebih banyak gadis yang jadi pelayan-pelayan altar, anak-nak lelaki kehilangan minat atau bahkan keluar. Jika hal ini kasusnya, temukan cara-cara untuk mengatasi hal ini.

12) Memiliki seorang konsultan dari luar untuk mengevaluasi struktur organisatoris paroki untuk mengetahui bagaiamana baiknya setiap organisasi dan pelayanan, meliputi dewan paroki dan dewan keuangan, melayani para warga paroki dan terbukan pada komunitas yang lebih luas. Setelah semua evaluasi di atas lengkap, dewan paroki memberi rekomendasi organisasi- organisasi mana yang dapat dilanjutkan, diubah, digabung, dikuatkan atau dihentikan.

13) Lakukan suatu evaluasi tahunan mengenai keefektifan staf profesional, termasuk bagaimana mereka bekerja bersama, kontribusi-kontribusi mereka, kekuatan-kekutan dan ketegangan-ketegangan dan keadilan akan gaji-gaji mereka, keungan dan harapan waktu kerja mereka.

14) Rencanakan untuk para staf suatu hari untuk berefleksi guna menguji hasil pertemuan pertemuan, pembaharuan secara profesional, hari-hari rekoleksi dan proses pembaharuan lainnya, seperti pembaharuan, koinonia, dan komunitas iman yang kecil. 
15) Mintalah ketua dari semua pelayan paroki untuk menguji misi paroki untuk mengetahui bagaimana hal ini telah ditemukan dan jika banyak perubahan, apakah itu sesuai dengan permintaan.

16) Sediakanlah bagi para warga paroki yang tertarik suatu daftar agen-agen pelayan sosial, dimana mereka dapat menjadi sukarelawan.

17) Mintalah komite hidup rohani untuk mempelajari keuntungan-keuntungan penyewaan suatu konselor spiritual paruh waktu atau penuh untuk mempertinggi kehidupan rohani dari paroki secara menyeluruh, berurusan dengan berbagai pelayanan khusus dan membantu para guru dan anak-anak di sekolah katolik atau sekolah kegamaaan paroki.

\section{Endnote:}

${ }^{1}$ Dosen tetap bidang ilmu Humaniora di STP-IPI Malang Prodi Pelayanan Pastoral.

${ }^{2}$ Bagian ini disadur dari buku USCCB Publishing (ed.), Sons and Daughters of the Light: A Pastoral Plan for Ministry with Young Adults, (United States Conference of Catholic Bishops, 2010)

${ }^{3}$ Mary Elizabeth O’Brien, Parish Nursing : Healthcare Ministry within the Church, (London: Jones and Bartlett Publishers, 2003), hal. 48.

${ }^{4}$ Bdk. Jakobus Tarigan, Dari Gereja Untuk Gereja: Kisah Perjalanan Seorang Imam, (Jakarta: Grasindo, Hal.2.

5 Howard John Clinebell, Tipe-Tipe Dasar Pendampingan dan Konseling Pastoral, (Yogyakarta: Kanisius, 2002), hal. 454.

${ }^{6}$ Anna Marie Eckert, Total Youth Ministry, (United States of America: Saint Mery's Press, 2004), hal. 25.

${ }^{7}$ Donal Dorr, Option For The Poor and for the Earth From Leo XIII to Pope Francis, (New York: Orbis Books, 2016), hal. Bdk. Rohan Michael Curnow, The Preferential Option for the Poor: A Short History and a Reading Based on the Thought of Bernard Lonergan, (Australia : Marquette University Press, 2012).

${ }^{8}$ Franz -Josef Eilers (Penterj.), Berkumunikasi dalam Pelayanan dan Misi, (Yogyakarta: Kanisius, 2012), hal. 188.

\section{Kepustakaan:}

\section{Dokumen Gereja}

R. Hardawiryana. Dokumen Konsili Vatikan II. Jakarta: Dokumentasi dan Penerangan KWI, 1992.

Susanto, Harry (Penterj.). Kompendium Katekismus Gereja Katolik. Yogyakarta: Kanisius, 2013.

\section{$\underline{\text { Buku-buku }}$}

Brian J. Mahan, Michael Warren and David F. White. Awakening Youth Discipleship, Wipf and Stock Publishers, 2008.

Clinebell, Howard John. Tipe-Tipe Dasar Pendampingan dan Konseling Pastoral.Yogyakarta: Kanisius, 2002.

Curnow, Rohan Michael. The Preferential Option for the Poor: A Short History and a Reading Based on the Thought of Bernard Lonergan. Australia : Marquette University Press, 2012. 
Dorr, Donal. Option For The Poor and for the Earth From Leo XIII to Pope Francis. New York: Orbis Books, 2016.

Eckert, Anna Marie. Total Youth Ministry. United States of America: Saint Mery's Press, 2004.

Eilers, Franz -Josef (Penterj.). Berkumunikasi dalam Pelayanan dan Misi. Yogyakarta: Kanisius, 2012.

Flannery, Austin (ed.). Vatican Council II: Lumen Gentium (Dogmatic Constitution on the Church. United States of America: Liturgical Press, 2014.

Ken Johnson-Modragon (ed.). Pathways of Hope And Faith Among Hispanic Teens: Pastoral Reflections Strategies Inspired by the National Study of Youth and Religion. California: Instituto FeyVida, 2007.

O'Brien, Mary Elizabeth. Parish Nursing : Healthcare Ministry within the Church. London: Jones and Bartlett Publishers, 2003.

Thomas East, dkk. Leadership fot Catholic Youth Ministry A Comprehensive Resource. New London: Twenty-Third Publication, 2009.

Tarigan, Jakobus. Dari Gereja Untuk Gereja: Kisah Perjalanan Seorang Imam. Jakarta: Grasindo, 2012. 